\title{
Effect of Grain Size Changes on Corrosion Behavior of Copper Produced by Accumulative Roll Bonding Process
}

\author{
A. Nikfahm ${ }^{\text {a }}$ I. Danaea ${ }^{\text {**, A. Ashrafi }}$, M.R. Toroghinejad \\ ${ }^{a}$ Abadan Faculty of Petroleum Engineering, Petroleum University of Technology, Abadan, Iran \\ ${ }^{\mathrm{b}}$ Faculty of Engineering, ShahidChamran University, Ahvaz, Iran \\ 'Department of Materials Engineering, Isfahan University of Technology, Isfahan, Iran
}

Received: November 27, 2012; Revised: June 14, 2013

\begin{abstract}
The effect of changes in grain size on corrosion resistance of the pure tough pitch copper stripwas investigated in acidic and alkaline $\mathrm{NaCl}$ solutions. Accumulative roll bonding as sever plastic process was applied up to 8 cycles to produce the ultrafine graincopper. Polarization and electrochemical impedance tests were used for corrosion resistance investigations. Corrosion morphologies were analyzed by FE-SEM. Results showed that the corrosion resistance decreased up to cycle 2 and increased after rolled for the fourth time due to UFG grain formation after cycle 4 . The corrosion degradation in cycle 8 was uniformand it was more intergranular for the sample of cycle 2 and the unrolled counterpart.
\end{abstract}

Keywords: TEM, copper, ultrafine grain, impedance, corrosion

\section{Introduction}

During the last decade, a variety of techniques for fabrication of ultra-fine grained (UFG) materials with nanocrystalline or sub-microcrystalline structure were developed $^{1,2}$. Severe Plastic Deformation (SPD) can be explained as deformation to large strains below recrystallization temperature without intermediate thermal treatments that can result in UFG structures ${ }^{3-7}$. The accumulative roll bonding (ARB) is one of the severe plastic deformations that proposed by Saito et al. ${ }^{8}$. The advantage of this process is its applicability to large bulky materials ${ }^{9-12}$ and is a continuous process.

Copper and copper alloys are widely used in condenser and heat exchanger tubing materials, plate heat exchangers and in copper canisters as one of the radioactive waste container metalsand in other industries due to their high thermal conductivity, good corrosion resistance, and mechanical workability. New industrial challenges require the production of improved high strength/ductile materials, reflected by the research for over two decades on the nanostructured materials with a strong focus on copper. These materials can be used in the industries that heat transferring properties and strength of them is important. However, for the nanostructured or submicron copper to be widely used, it is necessary to study its properties in detail, such as corrosion resistance ${ }^{13}$. The corrosion behavior of the nanostructured copper produced bythe SPD methodsgained only limited attention. Up to now, the works in this field about copper material were restricted to the corrosion behavior of ECAPed copper with and without heat treatment in different solution ${ }^{14-16}$. The ARB method for producing the nano structured sheets is a new process in comparison with the ECAP process which the product

*e-mail: danaee@put.ac.ir of the ARB process can be easily used in the fabrication of heat transferring pipes and other equipment that needs sheets with better physical and mechanical properties ${ }^{17-21}$. So study of the corrosion behavior in ARBed sheets will be important in heat transferring field. As known, the severe plastic deformation and changing in microstructure to nano size occur in the ECAP and ARB processes. Pitting corrosion of ultra fine grains aluminum produced by accumulative roll bonding process was investigated ${ }^{21}$. It indicates that the formation of passive film is difficult with increase the cold deformations and pitting corrosion resistance of samples were diminished with increasing the number of ARB passes which is presumably due to increasing the defect density. There was not any work on the corrosion behavior of the ARBed copper in the different situation up to now. The investigation of this behavior in the ECAPed copper as the SPD method willberationalbecause in both process sever plastic deformation occurs and the new nanomicrostructure produced $^{14-16}$. Vinogradov et al..$^{22}$ have first reported the anodic polarization behaviour of UFG copper fabricated by Equal-channel angular pressing (ECAP) in modified Livingstonetchant, and concluded that the anodic current in UFG copperis higher in both active and passive regions than that of coarsegrained (CG) counterparts. However, the corroded surface appeared rather smooth with shallow corrosion grooves at the grain boundaries whereas deeper grooves were formed within the grain boundaries in CG copper. Xu et al. ${ }^{14}$ studied the corrosion behavior in Hanks solution. They showed that the corrosion current of ECAPed copper in Hanks solution is higher than that of the coarse-grained copper ${ }^{14}$. Yamasaki et al..$^{23}$ investigated the stress-corrosion cracking (SCC) of the ultra-fine grain copper produced by ECAP method in $1 \mathrm{M} \mathrm{NaNO}_{2}$ aqueous 
solution. They found that the UFG copper possesses notably better resistance to SCC when compared to its coarse-grain counterpart $^{23}$. Miyamoto et al. ${ }^{15}$ reported that the UFG copper exhibited a lower corrosion current incomparison with that inits recrystallized coarsegrain (CG) counterpart in Livingstone etchant ${ }^{15}$. The unaffected general corrosion characteristics and homogeneous damage in the UFG copper in $3 \% \mathrm{NaCl}, 1 \mathrm{M} \mathrm{HCl}$ and the standard Livingston solution was reported by Janecek et al. ${ }^{24}$. The literature shows that there are littlediscussionsand reports about the extracted results. Due to different corrosion behavior of the UFG copper in different studied environments, it is necessary to investigate the corrosion behavior of copperin any specific environment. The aim of this study is to evaluate the electrochemical corrosion behavior of the pure copperstrip fabricated by $\mathrm{ARB}$ processin alkaline and acidic $\mathrm{NaCl}$ aqueous solution at the ambient temperature.

\section{Experimental Procedure}

\subsection{Specimen preparation}

The material was tough pitch copper $(99.9 \%)$. The initial sheets with $1 \mathrm{~mm}$ in thickness were cut into the dimensions $30 \mathrm{~mm}$ wide and $300 \mathrm{~mm}$ long and then subjected in the ARB process. One side of the surface of the sheets was degreased by acetone and wire-brushed. After the surface treatment, two pieces of the sheets were stacked so that the brushed surfaces were in contact and were fixed to each other tightly by copper wires and then rolled. The roll diameter was $127 \mathrm{~mm}$, and the rolling speed was about $6 \mathrm{~m} / \mathrm{min}$. The ARB processes up to 8 cycles were performed at the ambient temperature without lubrication. The sheets were air-cooled after roll bonding. Samples with dimensions of $7 \mathrm{~mm} \times 15 \mathrm{~mm}\left(\right.$ Area $\left.\approx 1 \mathrm{~cm}^{2}\right)$ were prepared from the rolled copper sheets and were covered by epoxy resin leaving only the $1 \mathrm{~cm}^{2}$ surface for corrosion tests. The samples of the cycle no 1, 2, 4, 6 and 8 were used for the comparing the corrosion behavior with the unrolledcopper strip. The chemical compositions of tough pitch copper have been shown in Table 1.

\subsection{Corrosion experiments}

Electrochemical experiments were performed using a three electrode cell at $25 \pm 1{ }^{\circ} \mathrm{C}$, in 3.5 wt. (\%) $\mathrm{NaCl}$ aqueous solution with $\mathrm{pH}=2$, and 11 . A platinum plate and a saturated $\mathrm{Ag} / \mathrm{AgClelectrode}$ were served as the counter and the reference electrode, respectively. The polarization and electrochemical impedance spectroscopy (EIS) tests were performed on an AutoLab PGSTAT 302N potentiostat system. The frequency range was from $100 \mathrm{kHz}$ to $10 \mathrm{mHz}$ using voltage amplitude of $10 \mathrm{mV}$. Fitting of experimental impedance spectroscopy data to the proposed equivalent circuit was done by means of home written least square software based on the Marquardt method for the optimization of functions and Macdonald weighting for the real and imaginary parts of the impedance ${ }^{25,26}$. The potentiodynamic polarization tests were carried out at the scanning rate of $1 \mathrm{mVs}^{-1}$ from $-0.45 \mathrm{~V}$ lower than OCP up to $0.35 \mathrm{~V}$ above the $\mathrm{OCP}$ in $\mathrm{pH}=2$ and up to sudden increase
Table 1. Specification of initial copper strip.

\begin{tabular}{|c|c|}
\hline Material & Chemical composition \\
\hline Tough pitch copper & $\begin{array}{l}\mathrm{Cu} 99.9 \% \text { (mass), Oxygen } \sim 250 \mathrm{ppm}, \\
\text { Other impurities } \sim \text { less than } 20 \mathrm{ppm}\end{array}$ \\
\hline
\end{tabular}

in the anodic current in $\mathrm{pH}=11$. Before each test, the samples were immersed into the electrolyte for $20 \mathrm{~min}$ to stabilize the open-circuit potential. The morphologies of the corroded surfaces after polarization testswere examined using FESEMHITACHI S-4160 Scanning Electron Microscopy forthe samples of cycle 2, 8 and the unrolled one.

\section{Results and Discussion}

\subsection{TEM}

Figure 1 shows the TEM microstructures and corresponding SAD patterns observed at rolling plane of ARB specimens produced by 1, 4 and 8 cycles. After 1 cycle of the ARB process the microstructure showed a mixture of non-deformed and deformed grains with some dislocation tangles (Figure 1a). It is not surprising because plastic deformation is inherently an inhomogeneous process. The SAD pattern of this sample was taken from a single crystal that shows no deformation has occurred in this grain. For the specimen after 4 cycles, the dislocation density increased and cell structures were observed. Also the microstructure became more uniform and some grains with an average grain size of $200 \mathrm{~nm}$ have formed. The SAD patterns of the 4 cycles ARB sample is more diffused than that of the single cycle sample and gradually evolves into ring pattern consisting of discrete spots (Figure 1b). This may indicates that examined area has subdivided into small domains with wide orientation spread. With increasing the strain up to 8 cycles, the dislocation density at grain interior seemed lower than those after 4 ARB cycles. It is noteworthy that small recrystallized grains were observed along with the ultrafine deformation microstructures, as seen in Figure 1c. The average grain size of these recrystallized grains is below $100 \mathrm{~nm}$, smaller than that after 4 cycles. The mean grain size of pure copper fabricated by ARB process has been reported about $260-300 \mathrm{~nm}$ by other researchers ${ }^{11,27,28}$. Also the SAD pattern became more ring-like with increasing strain up to 8 cycles, indicating the increment of a portion of high angle boundary.

\subsection{Electrochemical results}

The potentiodynamic polarization curves for the $\mathrm{ARBed} \mathrm{Cu}$ in comparison with the coarse grain $\mathrm{Cu}$ in $3.5 \%$ $\mathrm{NaCl}$ with $\mathrm{pH}=2$ and $\mathrm{pH}=11$ are shown in Figure 2 and 3, respectively. The general shape of the ARBed samples polarization curves did not change substantially with that of the CG samples in both the acidic and alkaline solution, reflecting similar dissolution behaviors of samples in each environment. All copper samples display an active-passivetranspassive behavior in $3.5 \% \mathrm{NaCl}$ with $\mathrm{pH}=11$. As can be seen, a single passive region was obtained which associated with the cuprous oxide $\mathrm{Cu}_{2} \mathrm{O}$ film formation on the specimen's surfaces which is clear in the FE-SEM images of 

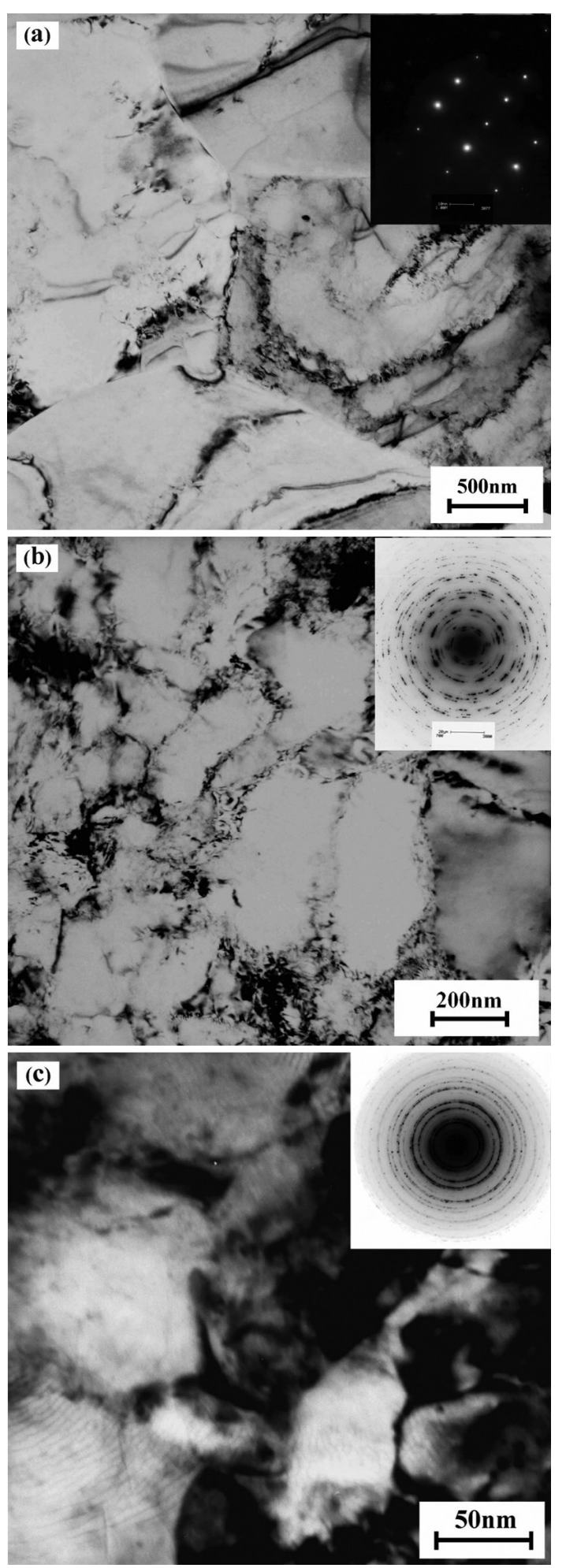

Figure 1. Typical TEM micrographs and the matching SAD patterns of ARB processed copper by (a) 1 cycle, (b) 4 cycles and (c) 8 cycles.

corroded surfaces. In the anodic region of polarization plots in acidic solution, the cupric ions produced and the current density reaches to a maximum amount. The formation of $\mathrm{CuCl}$ started, and the current decreased to its minimum

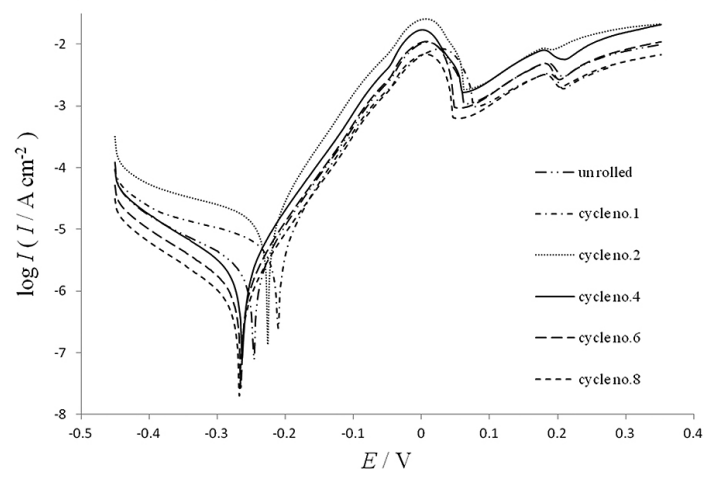

Figure 2. Polarization curves of unrolled and ARBed copper samples in $3.5 \% \mathrm{NaCl}$ with $\mathrm{pH}=2$ at $25 \pm 1{ }^{\circ} \mathrm{C}$.

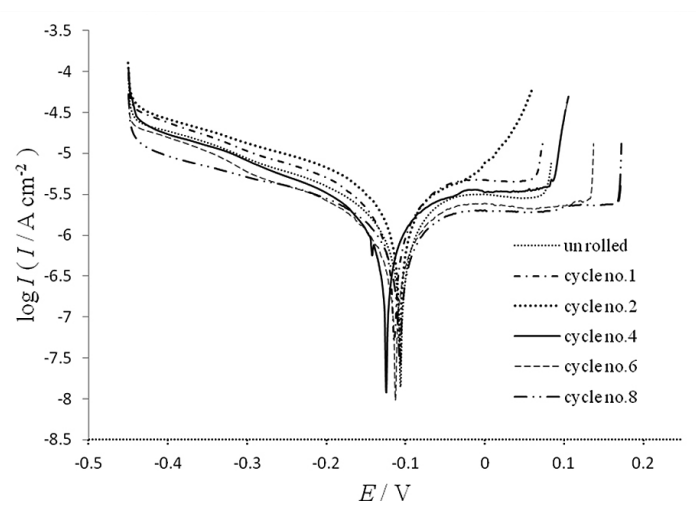

Figure 3. Polarization curves of unrolled and ARBed copper samples in $3.5 \% \mathrm{NaCl}$ with $\mathrm{pH}=11$ at $25 \pm 1{ }^{\circ} \mathrm{C}$.

value. After electrode passivation, the current was increased due to instability of $\mathrm{CuCl}$ and reaction of $\mathrm{Cl}^{-}$with $\mathrm{CuCl}$. Soluble $\mathrm{CuCl}_{2}^{-}$species formed and the corrosion process goes back, and $\mathrm{CuCl}_{2}^{-}$diffusion to solution controlled the corrosion. Therefore, the peaks of the polarization curves are related to formation of these compounds ${ }^{29}$.

The results for corrosion current densities $\left(I_{\text {corr }}\right)$ and other parameters summarized in Table 2, and 3 in acidic and basic solution. The highest corrosion current obtained for cycle 2 , and the minimum amount was for cycle 8 . The corrosion behavior was the same in all cycles. As can be seen in Table 2 and 3 , after cycle 4 corrosion current has been decreased in both solutions whereas the current was ascending until cycle 2 . These variations attributed to the microstructure of the samples that has been changed through the ARB process. This decrease in tendency to dissolution after cycle 4 isrelated to the microstructure stability. After cycle 4, the UFG grains have been formed which the UFG size in cycle 8 was lower than $100 \mathrm{~nm}$. It can be concluded that the stability in upper cycles is due to the UFG formation. The highest corrosion current and more degradation in cycle 2 (Figure 2 and 3 ) has confirmed instability of cycle 2 . Generally, with application of cold work on metals, due to some plastic deformation external energy induced in the metal, and the structure became unstable. In this case with the $\mathrm{ARB}$ process the microstructure becomes unstable. With 
Table 2. Corrosion parameters for unrolled and ARBed copper samples in $3.5 \% \mathrm{NaCl} \mathrm{pH}=2$ at $25 \pm 1{ }^{\circ} \mathrm{C}$.

\begin{tabular}{|c|c|c|c|c|c|c|}
\hline Sample & $\underset{/ \mu \mathrm{Acorr}^{-2}}{I_{\text {con }}}$ & $\begin{array}{l}-E_{\text {corr }} \\
/ \mathbf{V}\end{array}$ & $\begin{array}{c}\beta_{c} \\
/ m \operatorname{dec}^{-1}\end{array}$ & $\begin{array}{c}\beta_{\mathrm{a}} \\
/ \mathrm{mV} \text { dec }^{-1}\end{array}$ & 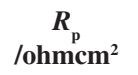 & $\begin{array}{c}\text { CR } \\
\text { / } \text { mmyear }^{-1}\end{array}$ \\
\hline Unrolled & 2.55 & 0.246 & 0.198 & 0.066 & $8.39 \times 10^{3}$ & $5.91 \times 10^{-2}$ \\
\hline Cycle no.1 & 2.80 & 0.210 & 0.243 & 0.067 & $8.14 \times 10^{3}$ & $6.49 \times 10^{-2}$ \\
\hline Cycle no.2 & 3.37 & 0.220 & 0.204 & 0.066 & $6.39 \times 10^{3}$ & $7.81 \times 10^{-2}$ \\
\hline Cycle no. 4 & 2.68 & 0.257 & 0.228 & 0.066 & $8.23 \times 10^{3}$ & $6.21 \times 10^{-2}$ \\
\hline Cycle no.6 & 1.67 & 0.264 & 0.196 & 0.066 & $1.28 \times 10^{4}$ & $3.87 \times 10^{-2}$ \\
\hline Cycle no.8 & 1.45 & 0.267 & 0.162 & 0.066 & $1.39 \times 10^{4}$ & $3.36 \times 10^{-2}$ \\
\hline
\end{tabular}

Table 3. Corrosion parameters for unrolled and ARBed copper samples in $3.5 \% \mathrm{NaCl} \mathrm{pH}=11$ at $25 \pm 1^{\circ} \mathrm{C}$.

\begin{tabular}{|c|c|c|c|c|c|c|}
\hline Sample & $\begin{array}{c}I_{\text {corr }} \\
/ \mu \mathrm{Acm}^{-2}\end{array}$ & $\begin{array}{c}-E_{\text {corr }} \\
/ \mathrm{V}\end{array}$ & $\begin{array}{c}\beta_{c} \\
/ m V \operatorname{dec}^{-1}\end{array}$ & $\begin{array}{c}\beta_{\mathrm{a}} \\
/ \mathrm{mV} \mathrm{dec}^{-1}\end{array}$ & $\underset{/ o h m_{\mathrm{p} m}^{2}}{R^{2}}$ & $\begin{array}{c}\text { CR } \\
\text { / } \text { mmyear }^{-1}\end{array}$ \\
\hline Unrolled & 2.15 & 0.116 & 0.232 & 0.172 & $1.99 \times 10^{4}$ & $4.98 \times 10^{-2}$ \\
\hline Cycle no.1 & 2.32 & 0.122 & 0.262 & 0.168 & $1.91 \times 10^{4}$ & $5.38 \times 10^{-2}$ \\
\hline Cycle no.2 & 2.97 & 0.118 & 0.273 & 0.181 & $1.59 \times 10^{4}$ & $6.88 \times 10^{-2}$ \\
\hline Cycle no.4 & 2.06 & 0.128 & 0.181 & 0.130 & $1.59 \times 10^{4}$ & $4.77 \times 10^{-2}$ \\
\hline Cycle no.6 & 1.49 & 0.121 & 0.156 & 0.123 & $2.00 \times 10^{4}$ & $3.45 \times 10^{-2}$ \\
\hline Cycle no. 8 & 1.05 & 0.117 & 0.109 & 0.089 & $2.00 \times 10^{4}$ & $2.43 \times 10^{-2}$ \\
\hline
\end{tabular}

cell and UFG formation after cycle no.4, the free energy of structure becomes lower, and the microstructure will be more stable than the lower cycles.

Another reason for lower corrosion current in upper cycles can be the interaction in cathodic reactions. The grain interiors are the cathodic and the grain boundaries are the anodic sites due to their lower potential in comparing with the grain interiors. So in upper cycles the cupric ions which produced in the anodic sites (grain boundaries), must participate in cathodic reaction in cathodic sites due to the lower grain size. Decrease incathodic sites (grain interior) to nanoscale, leads to control the corrosion process due to cathodic control. In other words, the cupric ions diffuse and cover the grain interior and interact in the reduction reactions, and therefore the anodic reaction is decreased. Miyamoto et al. ${ }^{15}$ found that the reasons of decrease in the corrosion current of the ECAPed copper are the interaction in the cathodic reaction.

In Figure 2, it can be seen that the critical current for first passive $(\mathrm{CuCl})$ formation in cycle 2 is higher than other samples. This is due to existence of more anodic and active sites in cycle 2 and refers to the unstable microstructure of this sample in comparison to the others, which leads to higher kinetics of anodic reactions. Also the short passive domain of the ARBed sample cycle 2 in $\mathrm{pH}=11$ is in agreement with the high corrosion current of the ARBed sample cycle 2 and show instability of passive layer in this sample.

The steady state anodic current density after surface passivationin $\mathrm{pH}=2$ was highest in the cycle no. 2 . This current characterizes the dissolution rate in the passive state. Therefore, the corrosion resistance of this sample will be the smallest in comparing with other samples. The anodic currents for some samples in $\mathrm{pH}=2$ seen to coincide on each other and the difference between them seem to be low, but the cathodic currents were more different from each other.
This means that the corrosion resistances influenced by the cathodic reactions rather than the anodic ones. Analysis of the polarization curves recorded in $\mathrm{pH}=11$, showed that the anodic polarization behavior of copper included transition from active to passive region with the $\mathrm{Cu}_{2} \mathrm{O}$ film formation. The cubic structured product in alkaline $\mathrm{NaCl}$ solution has been reported by others ${ }^{30}$. In the passive region, the formation of $\mathrm{Cu}_{2} \mathrm{O}$ occurred ${ }^{31}$, also in the active region probably unstable $\mathrm{CuCl}$ or $\mathrm{CuCl}_{2}^{-}$or copper ions have been formed. The sudden increase of the current at the higher potentials is due to film breakdown and formation of the poor films such as $\mathrm{CuO}$ and $\mathrm{Cu}(\mathrm{OH})_{2}$. Other authors explained the current increasing by the formation of soluble complexes ${ }^{31}$. From thermodynamic view, the lower transpassive potential, the lower energy needed to dissolve the layer. Therefore, passive layer of the cycle no. 2 dissolved rapidly in comparing with others and this layer for cycle no. 8 was more stable and protective. In Figure 3 it can be easily seen that the passive current of cycle 8 was lower than the others, and it was highest for cycle 2 . Therefore the stability of the layer in cycle 8 was higher and the UFG microstructure showed better corrosion resistance in comparing with the others.

Figure 4 shows the typical Nyquist plots obtained for the different copper samples at an open-circuit potential after 20 min immersion in $3.5 \% \mathrm{NaCl}$ with $\mathrm{pH}=2$. For the purpose of impedance spectra analysis, the experimental data were fitted using equivalent circuit, as shown in Figure 5 and the circuit elements were obtained. The depressed semicircle in the high frequency can be related to the charge transfer resistance and the double-layer capacitance. To obtain a satisfactory impedance simulation of copper, it is necessary to replace the capacitor $(C)$ with a constant phase element (CPE) $Q$ in the equivalent circuit $^{32}$. The most widely accepted explanation for the presence of $C P E$ behavior and depressed semicircles on solid electrodes is microscopic roughness, causing an inhomogeneous distribution in 
the solution resistance as well as in the double-layer capacitance $^{33}$. The impedance of the $C P E$ is defined as $Z_{C P E}=1 / Q(i w)^{n}$, where $Q$ is a capacitive parameter related to the average double layer capacitance $\left(C_{\mathrm{dl}}\right)$, and $n$ is a dimensionless parameter related to the constant phase angle. In equivalent electrical circuit, $R, C P E_{\mathrm{dl}}, R_{\mathrm{ct}}$ and $W$ represent solution resistance, a constant phase element corresponding to the double layer capacitance, the charge transfer resistance andthe Warburg impedance. This electrochemical circuit fitted acceptably on the EIS spectra with mean square error less than 0.05. Table 4 illustrates the equivalent circuit parameters for the impedance spectra of copper samples in

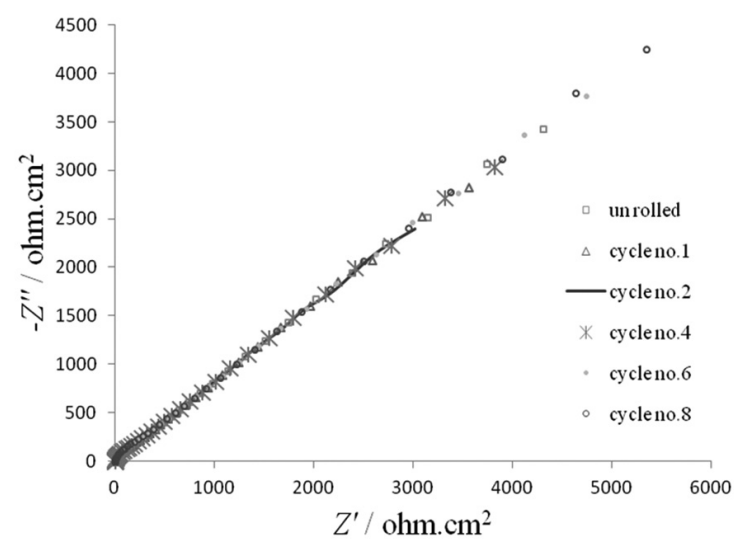

Figure 4. Typical Nyquist impedance plots for ARBed and unrolled copper samples in $3.5 \% \mathrm{NaCl}$ at $25 \pm 1{ }^{\circ} \mathrm{C}$ with $\mathrm{pH}=2$.

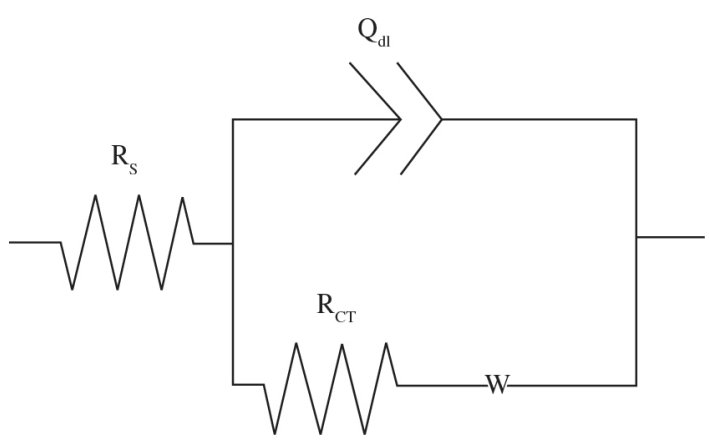

Figure 5. Equivalent circuit used to model impedance data for $\mathrm{ARBed}$ and unrolled copper samples in $3.5 \% \mathrm{NaCl}$ solution with $\mathrm{pH}=2$ at $25 \pm 1 \mathrm{C}$. acidic $\mathrm{NaCl}$ solution. The presence of Warburg impedance in lower frequencies shows that the corrosion is controlled by diffusion of products or aggressive ions through the corrosion product on the surface to/from the solution. Therefore diffusion of $\mathrm{Cl}^{-}$from the solution to the interface and reaction with the $\mathrm{CuCl}$ layer and finally diffusion of soluble $\mathrm{CuCl}_{2}^{-}$to the solution have been controlled the corrosion rate ${ }^{31}$.

The typical Nyquist plots obtained for the different copper samples at the open circuit potential in $3.5 \% \mathrm{NaCl}$ with $\mathrm{pH}=11$ are shown in Figure 6. The Nyquist diagrams consisted of two slightly depressed overlapping capacitive semicircles in the high and low frequency sides of the spectrum. The depressed semicircle in the high-frequency region can be related to the combination of charge transfer resistance and the double-layer capacitance. The lowfrequency semicircle was attributed to the oxide film formed on the copper surface. The equivalent circuit for the experimental dates in $\mathrm{pH}=11$ has been shown in Figure 7 which $R_{\mathrm{f}}$ and $Q_{\mathrm{f}}$ are the resistance and capacitance of the film formed on the copper surface. Table 5 illustrates the equivalent circuit parameters for the impedance spectra of copper samples in basic $\mathrm{NaCl}$ solution.

From the EIS diagrams it is clear that the shapes of the impedance plots are the same. It means that the corrosion mechanism was the same for all samples, and the little differences are related to their microstructures. This was in agreement with the polarization behavior that discussed in the last section. It is clear that the diameter of the obtained semicircle in cycle 8 is larger than the cycle 2 and the unrolled sample. This means that the polarization resistance is larger in cycle 8. Compactness of the film seems to lock the charge transfer sites on the UFG surfaces.

The ARB processes diminish $R_{\mathrm{f}}$ and $R_{\mathrm{ct}}$ until cycle 2 and after that, their amounts increased. The film and charge transfer resistance improved in cycle 4, 6 and 8 in comparing with the lower cycles. Therefore, the corrosion resistance increased after cycle 4, which are due to the UFG formation, and lead to blocking of the active sites by stable products.

\subsection{Morphology of corroded surfaces after polarization}

Because of the maximum corrosion current in cycle 2 and the minimum amount in cycle 8, these samples have been selected to comparison their corroded surface with unrolled sample. Figure 8 shows the surface morphologies of the samples after potentiodynamic polarization test in

Table 4. Electrochemical parameters calculated from EIS measurements on copper electrode in $3.5 \% \mathrm{NaCl}$ solution with $\mathrm{pH}=2$, at $25 \pm 1{ }^{\circ} \mathrm{C}$ using equivalent circuit presented in Figure 4.

\begin{tabular}{lccccc}
\hline \multicolumn{1}{c}{ Sample } & $\begin{array}{c}\boldsymbol{R}_{\mathrm{s}} \\
/ \Omega \mathbf{c m}^{2}\end{array}$ & $\begin{array}{l}\boldsymbol{Q}_{\mathrm{dl}} \\
/ \mathbf{F}\end{array}$ & $\boldsymbol{n}$ & $\begin{array}{c}\boldsymbol{R}_{\mathrm{ct}} \\
/ \Omega \mathbf{c m}^{2}\end{array}$ & $\boldsymbol{W} / \Omega^{-1} \mathbf{c m}^{-2} \mathbf{s}^{\mathbf{1} 2}$ \\
\hline Unrolled & 3.393 & $4.76 \times 10^{-5}$ & 0.86 & 251.2 & $6.74 \times 10^{-4}$ \\
Cycle no.1 & 2.734 & $5.77 \times 10^{-5}$ & 0.87 & 207.2 & $8.17 \times 10^{-4}$ \\
Cycle no.2 & 2.158 & $6.81 \times 10^{-5}$ & 0.86 & 175.8 & $9.64 \times 10^{-4}$ \\
Cycle no.4 & 2.545 & $5.37 \times 10^{-5}$ & 0.86 & 222.6 & $7.61 \times 10^{-4}$ \\
Cycle no.6 & 3.084 & $4.33 \times 10^{-5}$ & 0.87 & 276.2 & $6.13 \times 10^{-4}$ \\
Cycle no.8 & 3.821 & $3.84 \times 10^{-5}$ & 0.86 & 311.2 & $5.44 \times 10^{-4}$ \\
\hline
\end{tabular}


$\mathrm{pH}=2$. Different microstructure is seen in the cycle no. 2 in comparing with the unrolled one. The grain boundary attacks are visible clearly in the unrolled and cycle no. 2 samples. As can be seen, the corroded grain boundaries are narrow in the unrolled sample in comparing to the cycle no. 2 and the volume fraction of them is lower than that of the cycle no.2. Because of the dislocation accumulation in the grain boundaries of cycle 2 , the boundaries were attacked more and the grooves have been broader than the unrolled material. Some grains were deformed in cycle 2 and the dislocation density has been increased in the grain interiors and boundaries. Therefore, the surface was rougher than theunrolled sample. The corrosion products in the grain boundaries of the cycle no. 2 have been piecemealed because the density of dislocations is much in this sample. The polarized surface of the cycle no. 8 seems to be smoother

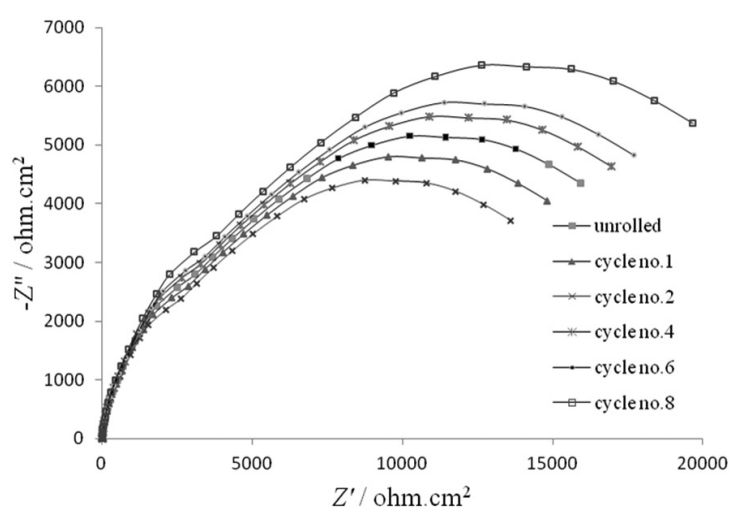

Figure 6. Typical Nyquist impedance plots for ARBed and unrolled copper samples in $3.5 \% \mathrm{NaCl}$ at $25 \pm 1{ }^{\circ} \mathrm{C}$ with $\mathrm{pH}=11$. than the unrolled and cycle 2. As mentioned before, the dislocation density increased with ARB process until the dislocations lead to the new cells and UFG grains were uniformly formed in cycle 8 . When aggressive ions attack to this surface, it corroded uniformly than the lower cycles because the potential difference in entire surface is very low. As seen in the surface of cycle 8 , the grain boundaries have not been attacked. It understands that the distribution of the free energy and potential difference is homogeneous and uniform in the higher cycles. Therefore, the corrosion type of the samples has been changed from intergranular in lower cycles to uniform in upper cycles as shown in Figure 8.

The morphologies of samples in $\mathrm{pH}=11$ has been shown in Figure 9. The appearance of corroded surface in this solution is different with $\mathrm{pH}=2$. The grain boundary attack is not seen not only for unrolled but also for cycle 2 and 8 .

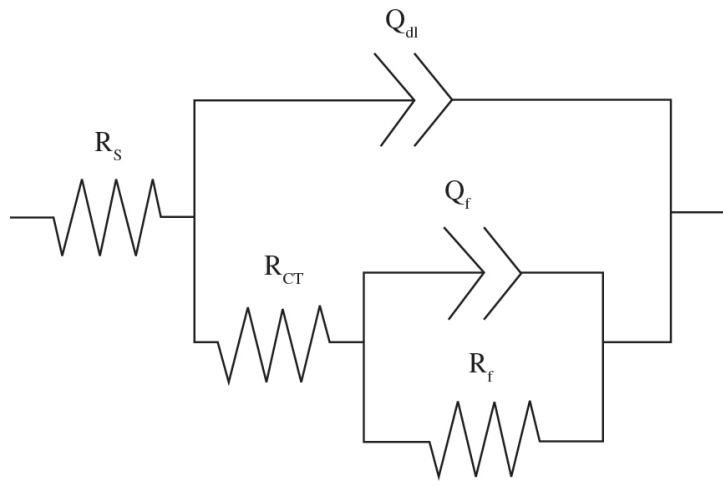

Figure 7. Equivalent circuit used to model impedance data for ARBed and unrolled copper samples in $3.5 \% \mathrm{NaCl}$ solution with $\mathrm{pH}=11$ at $25 \pm 1{ }^{\circ} \mathrm{C}$.

Table 5. Electrochemical parameters calculated from EIS measurements on copper electrode in $3.5 \% \mathrm{NaCl}$ solution with $\mathrm{pH}=11$, at $25 \pm 1^{\circ} \mathrm{C}$ using equivalent circuit presented in Figure 6 .

\begin{tabular}{lccccccc}
\hline \multicolumn{1}{c}{ Sample } & $\begin{array}{c}\boldsymbol{R}_{s} \\
/ \Omega \mathbf{c m}^{2}\end{array}$ & $\begin{array}{c}\boldsymbol{Q}_{d l} \\
/ \mathbf{F}\end{array}$ & $\boldsymbol{n}_{\boldsymbol{l}}$ & $\begin{array}{c}\boldsymbol{R}_{c t} \\
/ \Omega \mathbf{c m}^{2}\end{array}$ & $\begin{array}{c}\boldsymbol{Q}_{f} \\
/ \mathbf{F}\end{array}$ & $\boldsymbol{n}_{2}$ & $\begin{array}{c}\boldsymbol{R}_{f} \\
/ \Omega \mathbf{c m}^{2}\end{array}$ \\
\hline Unrolled & 2.842 & $2.18 \times 10^{-5}$ & 0.9 & 3450 & $1.26 \times 10^{-3}$ & 0.58 & $1.99 \times 10^{4}$ \\
Cycle no.1 & 2.668 & $2.32 \times 10^{-5}$ & 0.89 & 3199 & $1.44 \times 10^{-3}$ & 0.58 & $1.74 \times 10^{4}$ \\
Cycle no.2 & 2.278 & $2.72 \times 10^{-5}$ & 0.89 & 2939 & $1.58 \times 10^{-3}$ & 0.57 & $1.59 \times 10^{4}$ \\
Cycle no.4 & 2.482 & $2.50 \times 10^{-5}$ & 0.9 & 3664 & $1.35 \times 10^{-5}$ & 0.57 & $1.86 \times 10^{4}$ \\
Cycle no.6 & 2.964 & $2.09 \times 10^{-5}$ & 0.9 & 3820 & $1.09 \times 10^{-5}$ & 0.57 & $2.08 \times 10^{4}$ \\
Cycle no.8 & 3.294 & $1.88 \times 10^{-5}$ & 0.9 & 4240 & $1.21 \times 10^{-6}$ & 0.57 & $2.31 \times 10^{4}$ \\
\hline
\end{tabular}
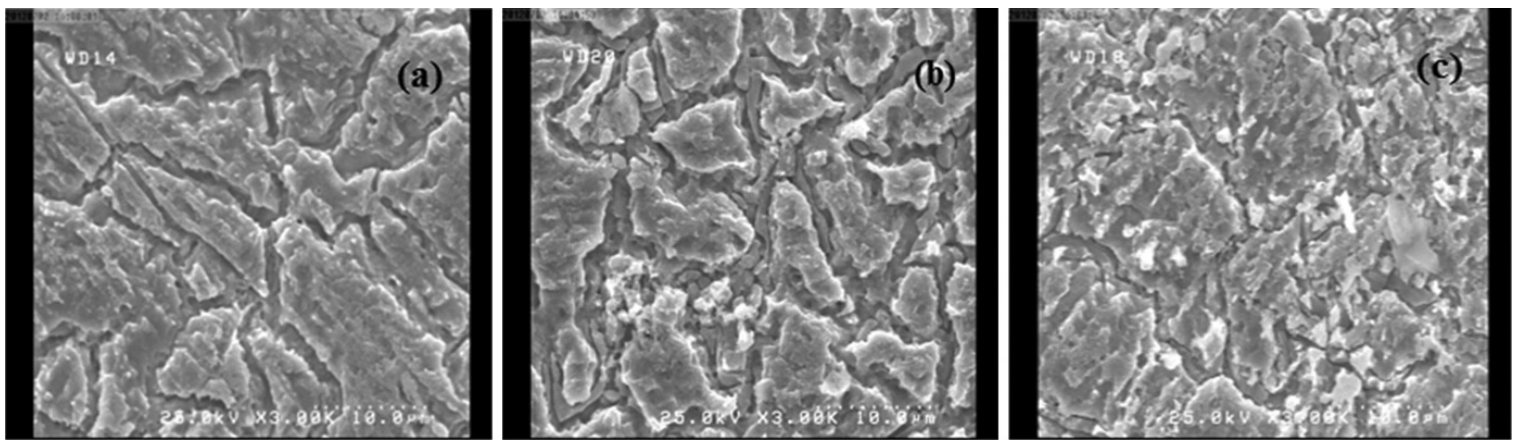

Figure 8. FE-SEM images of corroded surfaces after polarization in $3.5 \% \mathrm{NaCl}$ at $25 \pm 1^{\circ} \mathrm{C}$ with $\mathrm{pH}=2$ (a): unrolled, (b): cycle no.2, (c): cycle no.8. 

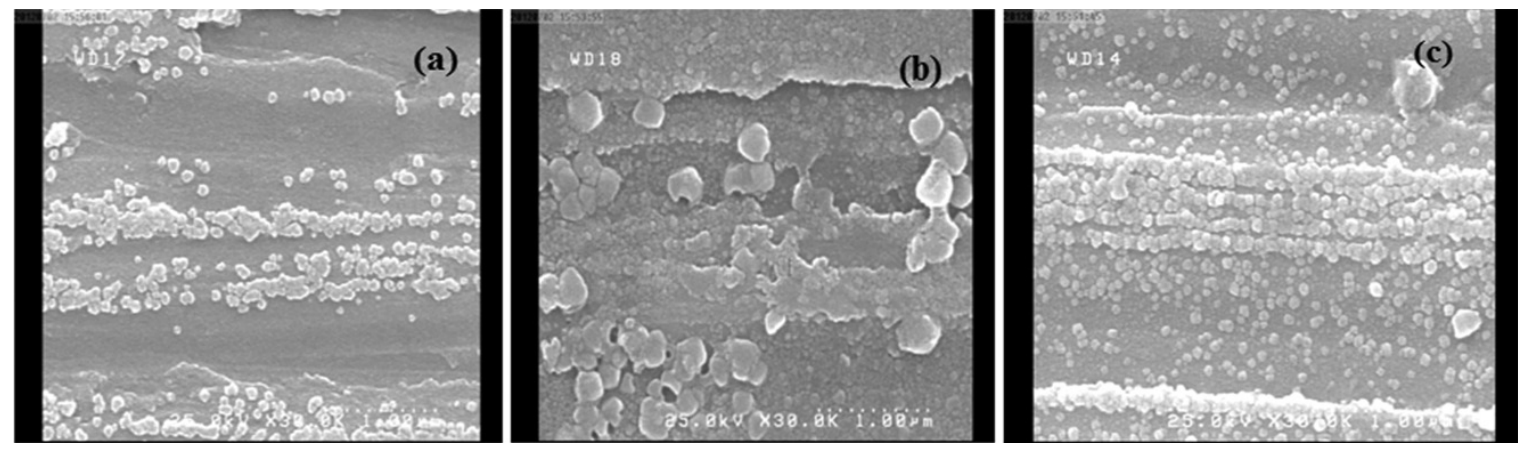

Figure 9. FE-SEM images of corroded surfaces after polarization in $3.5 \% \mathrm{NaCl}$ at $25 \pm 1{ }^{\circ} \mathrm{C}$ with $\mathrm{pH}=11$ (a): unrolled, (b): cycle no.2, (c): cycle no.8.

The cubic $\mathrm{Cu}_{2} \mathrm{O}$ products have been formed and covered the surface so the active site blocked and finally, the corrosion rate decreased. The surface of the sample of cycle 8 is covered with $\mathrm{Cu}_{2} \mathrm{O}$ more than others. The compactness of products is more in this sample. The dislocation accumulation in cycle 2 is more, and the microstructure inhomogeneity existed in this sample in comparing with the unrolled and cycle 8 . Therefore, the corrosion products were influenced by substrate and the surface of the cycle 2 degraded differently. In addition to decreasing the corrosion current in upper ARB cycles, another important result from images of the polarized samples is decreasing the grain boundary in upper cycles, which observed in FE-SEM images. This can be considered as a certain advantage of the ARBed copper in engineering applications.

\section{Conclusion}

Corrosion behavior of ARBed copper has been investigated in acidic and alkaline $3.5 \% \mathrm{NaCl}$ solution. The shape of the polarization curves and EIS plots generally was the same for all samples in both environments. This means that the corrosion mechanism does not change with the ARB process. The corrosion current of the ARBed copper increased until cycle 2 and decreased after cycle 4 because of cell and UFG formation after cycle no.4. The free energy of structure becomes lower, and the microstructure will be more stable than the lower cycles. Another reason for the lower corrosion current in upper cycles can be the interaction in cathodic reactions. The corrosion morphologies have been shown that the type of corrosion changed with ARB process, and uniform corrosion occurred in the upper cycle whereas in unrolled and cycle 2, intergranular corrosion has been occurred. This was due to homogeneity in the microstructure such as potential differences distributions and UFG grain formation after cycle 4 .

\section{Acknowledgements}

The authors would like to thank the Tabriz Oil Refining Company and Iranian nano technology initiative council for their financial support.

\section{References}

1. Gleiter H. Materials with ultrafine microstructures: Retrospectives and perspectives. Nanostructured Materials. 1992; 1:1-19. http://dx.doi.org/10.1016/09659773(92)90045-Y

2. Segal VM. Materials processing by simple shear. Materials Science and Engineering: A. 1995; 197:157-164. http://dx.doi. org/10.1016/0921-5093(95)09705-8

3. Cherukuri B, Nedkova TS and Srinivasan R. A comparison of the properties of SPD-processed AA-6061 by equal-channel angular pressing, multi-axial compressions/forgings and accumulative roll bonding. Materials Science and Engineering: A. 2005; 410-411:394-397. http://dx.doi.org/10.1016/j. msea.2005.08.024

4. Jiang J, Ma A, Saito N, Shen Z, Song D, Lu F et al. Improving corrosion resistance of RE-containing magnesium alloy ZE41A through ECAP. Journal of Rare Earths. 2009; 27:848-852. http://dx.doi.org/10.1016/S1002-0721(08)60348-8

5. Song D, Ma A, Jiang J, Lin P and Yang D. Corrosion behavior of ultra-fine grained industrial pure Al fabricated by ECAP. Transactions of Nonferrous Metals Society of
China. 2009; 19:1065-1070. http://dx.doi.org/10.1016/S10036326(08)60407-0

6. Chung M, Choi Y, Kim J, Kim Y and Lee J. Effect of the number of ECAP pass time on the electrochemical properties of $1050 \mathrm{Al}$ alloys. Materials Science and Engineering: A. 2004; 366:282291. http://dx.doi.org/10.1016/j.msea.2003.08.056

7. Brunner JG, Birbilis N, Ralston KD and Virtanen S. Impact of ultrafine-grained microstructure on the corrosion of aluminium alloy AA2024. Corrosion Science. 2012; 57:209-214. http:// dx.doi.org/10.1016/j.corsci.2011.12.016

8. Saito Y, Utsunomiya H, Tsuji N and Sakai T. Novel ultrahigh straining process for bulk materials-development of the accumulative roll-bonding (ARB) process. Acta Materialia. 1999; 47:579-583. http://dx.doi.org/10.1016/ S1359-6454(98)00365-6

9. Huang X, Tsuji N, Minamino Y and Hansen N. The 22nd Ris $\varnothing$ International Symposium on Materials Science. Roskilde, Denmark; 2001, p. 255.

10. Tsuji N, Saito Y, Lee SH and Minamino Y. ARB (Accumulative Roll-Bonding) and other new Techniques to Produce Bulk Ultrafine Grained Materials. Advanced Engineering 
Materials. 2003; 5:338-344. http://dx.doi.org/10.1002/ adem. 200310077

11. Shaarbaf $M$ and Toroghinejad MR. Nano-grained copper strip produced by accumulative roll bonding process. Materials Science and Engineering: A. 2008; 473:28-33. http://dx.doi. org/10.1016/j.msea.2007.03.065

12. Darmiani E, Danaee I, Golozar MA, Toroghinejad MR, Ashrafi A and Ahmadi A. Reciprocating wear resistance of Al-SiC nano-composite fabricated by accumulative roll bonding process. Materials \& Design. 2013; 50:497-502. http://dx.doi. org/10.1016/j.matdes.2013.03.047

13. Gordo PM, Duarte Naia M, Ramos AS, Vieira MT and Kajcsos Z. Positron studies on nanocrystalline copper thin films doped with nitrogen. In: Proceedings of the ICPA15 - 15th International Conference on Positron Annihilation; 2009; Kolkata, India. Kolkata; 2009.

14. Xu XX, Nie FL, Zhang JX, Zheng W, Zheng YF, Hu C et al. Corrosion and ion release behavior of ultra-fine grained bulk pure copper fabricated by ECAP in Hanks solution as potential biomaterial for contraception. Materials Letters. 2010; 64:524527. http://dx.doi.org/10.1016/j.matlet.2009.11.065

15. Miyamoto H, Harada K, Mimaki T, Vinogradov A and Hashimoto S. Corrosion of ultra-fine grained copper fabricated by equal-channel angular pressing. Corrosion Science. 2008; 50: 1215-1220. http://dx.doi.org/10.1016/j. corsci.2008.01.024

16. Son I, Nakano H, Oue S, Kobayashi S, Fukushima H and Horita Z. Effect of equal-channel angular pressing on pitting corrosion resistance of anodized aluminum-copper alloy. Transactions of Nonferrous Metals Society of China. 2009; 19:904-908. http:// dx.doi.org/10.1016/S1003-6326(08)60374-X

17. Darmiani E, Danaee I, Golozar MA and Toroghinejad MR Corrosion investigation of $\mathrm{Al}-\mathrm{SiC}$ nano-composite fabricated by accumulative roll bonding (ARB) process. Journal of Alloys and Compounds. 2013; 552:31-39. http://dx.doi.org/10.1016/j. jallcom.2012.10.069

18. Kadkhodaee M, Babaiee M, Manesh HD, Pakshir M and Hashemi B. Evaluation of corrosion properties of Al/ nanosilica nanocomposite sheets produced by accumulative roll bonding (ARB) process. Journal of Alloys and Compounds. 2013; 576:66-71. http://dx.doi.org/10.1016/j. jallcom.2013.04.090

19. Raducanu D, Vasilescu E, Cojocaru VD, Cinca I, Drob P, Vasilescu $\mathrm{C}$ et al. Mechanical and corrosion resistance of a new nanostructured $\mathrm{Ti}-\mathrm{Zr}-\mathrm{Ta}-\mathrm{Nb}$ alloy. Journal of the Mechanical Behavior of Biomedical Materials. 2011; 4:14211430. PMid:21783152. http://dx.doi.org/10.1016/j. jmbbm.2011.05.012

20. Wei W, Xia Wei K and Bo Du Q. Corrosion and tensile behaviors of ultra-fine grained $\mathrm{Al}-\mathrm{Mn}$ alloy produced by accumulative roll bonding. Materials Science and Engineering: A. 2007; 454-455:536-541. http://dx.doi.org/10.1016/j. msea.2006.11.063
21. Naeini MF, Shariat MH and Eizadjou M. On the chlorideinduced pitting of ultra fine grains 5052 aluminum alloy produced by accumulative roll bonding process. Journal of Alloys and Compounds. 2011; 509:4696-4700. http://dx.doi. org/10.1016/j.jallcom.2011.01.066

22. Vinogradov A, Mimaki T, Hashimoto S and Valiev RZ. On the corrosion behaviour of ultra-fine grain copper. Scripta Mater. 1999; 41:319-326. http://dx.doi.org/10.1016/S13596462(99)00170-0

23. Yamasaki T, Miyamoto H, Mimaki T, Vinogradov A and Hashimoto S. Stress corrosion cracking susceptibility of ultrafine grain copper produced by equal-channel angular pressing. Materials Science and Engineering: A. 2001; 318:122-128. http://dx.doi.org/10.1016/S0921-5093(01)01332-6

24. Janecek M, Hadzima B, Hellmig RJ and Estrin Y. The influence of microstructure on the corrosion properties $\mathrm{Cu}$ polycrystals prepared by ECAP. Kovove Materialy. 2005; 43:258-271.

25. Danaee I. Kinetics and mechanism of palladium electrodeposition on graphite electrode by impedance and noise measurements. Journal of Electroanalytical Chemistry. 2011; 662:415-420. http://dx.doi.org/10.1016/j. jelechem.2011.09.012

26. MacDonald JR. Note on the parameterization of the constantphase admittance element. Solid State Ionics. 1984; 13:147149. http://dx.doi.org/10.1016/0167-2738(84)90049-3

27. Jang YH, Kim SS, Han SZ, Lim CY, Kim CJ and Goto M. Effect of trace phosphorous on tensile behavior of accumulative roll bonded oxygen-free copper. Scripta Materialia. 2005, 52:2124. http://dx.doi.org/10.1016/j.scriptamat.2004.09.005

28. Han SZ, Lim C, Kim CJ and Kim S. Mechanical Properties of SPD (Severe Plastic Deformation) Processed Copper. Materials Science Forum. 2005; 475-479:3497-3501. http:// dx.doi.org/10.4028/www.scientific.net/MSF.475-479.3497

29. Li W, Hu L, Zhang S and Hou B. Effects of two fungicides on the corrosion resistance of copper in $3.5 \% \mathrm{NaCl}$ solution under various conditions. Corrosion Science. 2011; 53:735-745. http://dx.doi.org/10.1016/j.corsci.2010.11.006

30. Kear G, Barker BD and Walsh FC. Electrochemical corrosion of unalloyed copper in chloride media - a critical review. Corrosion Science. 2004; 46:109-135. http://dx.doi. org/10.1016/S0010-938X(02)00257-3

31. Antonijevic MM, Alagic SC, Petrovic MB, Radovanovic MB and Stamenkovic AT. The Influence of $\mathrm{pH}$ on Electrochemical Behavior of Copper in Presence of Chloride Ions. International Journal of Electrochemical Science. 2009; 4:516-524.

32. Danaee I, Niknejad Khomami M and Attar AA. Corrosion behavior of AISI 4130 steel alloy in ethylene glycol-water mixture in presence of molybdate. Materials Chemistry and Physics. 2012; 135:658-667. http://dx.doi.org/10.1016/j. matchemphys.2012.05.041

33. Danaee I and Noori S. Kinetics of the hydrogen evolution reaction on NiMn graphite modified electrode. International Journal of Hydrogen Energy. 2011; 36:12102-12111. http:// dx.doi.org/10.1016/j.ijhydene.2011.06.106 